\title{
Łukasz Sandera
}

Międzyuczelniany Instytut Muzyki Kościelnej w Krakowie

\section{Sprawozdanie z IX Dni Muzyki Kościelnej w Archidiecezji Krakowskiej}

W dniach 16-24 listopada 2013 roku zorganizowano IX Dni Muzyki Kościelnej w Archidiecezji Krakowskiej.

Ich obchody rozpoczęły warsztaty muzyczno-liturgiczne prowadzone przez: prof. Martę Kierską-Witczak (Wrocław), prof. Stanisława Krawczyńskiego (Kraków), ks. dra hab. Roberta Tyrałę (Kraków), s. dr hab. Susi Ferfoglię (Kraków), dra Tomasza Orlowa (Katowice), ks. dra Stanisława Mieszczaka (Kraków), dra Krzysztofa Michałka (Kraków). W warsztatach mogli wziąć udział wszyscy zainteresowani. W tematycznych grupach kilkuosobowych można było doskonalić umiejętności z zakresu: emisji głosu, prowadzenia zespołów wokalnych, chorału gregoriańskiego, improwizacji organowej, liturgiki i akompaniamentu liturgicznego.

Wieczorem w kościele pw. Najświętszej Maryi Panny z Lourdes odbył się koncert muzyki na chór i organy, w którym wystąili: Szilveszter Rostetter - organy, chór Schola Regina (Veszprem, Węgry), Rita Nagy Rostetter - dyrygent; Mieszany Chór Mariański, Jan Rybarski - dyrygent. W programie znalazły się kompozycje: Szilvesztra Rosttetera, Orlanda di Lasso, Mikołaja Gomółki, Williama Byrda, Franza Liszta, Maurice’a Duruflé, Jana Rybarskiego, Marka Jasińskiego, Józefa Świdra, Andrew Lloyda, Giuseppe Verdiego, ks. Eugeniusza Gruberskiego.

19 listopada w sali koncertowej Akademii Muzycznej odbyła się sesja naukowa zatytułowana Nobilis pulchritudo. W sesji głos zabrali następujący prelegenci: Marek Dyżewski (Wrocław) - Czy piękno zbawi nasz świat?, ks. dr Tomasz Bać (Rzeszów) - Czy można mówić o celebracji bez piękna i o pięknie bez celebracji? Estetyka liturgii, prof. dr hab. Wojciech Widłak (Kraków) - Muzyki krzewy ptonące. Oblicza piękna w twórczości kompozytorskiej ostatnich dekad, ks. dr Wiesław Hudek (Katowice) - Pieśn moja śpiewam Królowi (Ps 54, 2). O kategorii muzycznego piękna $w$ celebracji liturgicznej. Sesję naukową otworzył ks. dr hab. Robert Tyrała - dyrektor Międzyuczelnianego Instytutu Muzyki Kościelnej w Krakowie, a prowadził dr hab. Wiesław Delimat, prof. UPJPII. Sesja miała na celu przybliżenie uczestnikom zagadnienie piękna w różnych jego wymiarach. Został więc 
pogłębiony temat szlachetnego piękna obecnego w liturgii Kościoła rzymskokatolickiego i muzyce, szczególnie współcześnie tworzonej. Wyjątkowe miejsce miała refleksja dotycząca piękna w całym otaczającym człowieka świecie, przedstawiona syntetycznie, głęboko i w pięknej formie.

21 listopada w siedzibie ASM przy ul. Prostej w Krakowie odbył się Mistrzowski Kurs Emisji Głosu, prowadzony przez Alessandro Svaba z Włoch. W kursie mogli wziąć udział wszyscy zainteresowani tematyką emisji głosu. Wśród uczestników byli również studenci Międzyuczelnianego Instytutu Muzyki Kościelnej. Alessandro Svab dzięki indywidualnemu podejściu oraz zastosowaniu niekonwencjonalnych ćwiczeń fizycznych towarzyszących śpiewowi pomagał uczestnikom kursu w rozwiązywaniu nawet najtrudniejszych problemów emisyjnych.

Tego samego dnia w siedzibie Archidiecezjalnej Szkoły Muzycznej podczas uroczystych Nieszporów pobłogosławione zostały aula i organy firmy Karl Schuke z Berlina. Instrument zbudowano w latach 60 . XX wieku i był on własnością Uniwersytetu Muzycznego w Kolonii. W lipcu 2013 roku organy zostały sprowadzone do siedziby ASM przez firmę In Plenum PL Mariana Majchera, a następnie złożone przez organmistrza Lecha Skoczylasa. Organy posiadają 36 głosów, 3 manuały, mechaniczną trakturę gry, elektryczną trakturę rejestrów i połączeń, wiatrownice klapowo-zasuwowe oraz setzer na 10 tysięcy kombinacji. Uroczystości pobłogosławienia przewodniczył bp Tadeusz Pieronek. Podczas Nieszporów chór ASM pod dyrekcją dra hab. Wiesława Delimata, prof. UPJPII zaśpiewał Magnificat Johanna Pachelbela. Po uroczystości dr Anna Dzioba wykonała Preludium i Fuge Es-dur Jana Sebastiana Bacha BWV 552. Na organach akompaniował dr Krzysztof Michałek. Po uroczystości odczytany został list od ks. kard. Stanisława Dziwisza, który nadał Złoty Krzyż Zasługi za szerzenie kultury muzycznej mgr Lidii Skrzyniarz - ówczesnej wizytator Regionu Małopolskiego Centrum Edukacji Artystycznej.

22 listopada w kolegiacie św. Anny zorganizowano koncert, podczas którego zabrzmiało Requiem op. 48 Gabriela Faure oraz kompozycja Stephana Harrapa pt. Love vanquishes Death (było to prawykonanie tego utworu). W koncercie wystąpili: Anna Ciuła-Pehlken - sopran, Alessandro Svab - bas, Krzysztof Pawlisz - organy oraz chór Kantorei Sankt Barbara, chór Międzyuczelnianego Instytutu Muzyki Kościelnej, orkiestra L’Estate Armonico. Całość poprowadził dyrygent Wiesław Delimat. Koncert dedykowany był zmarłemu tragicznie śp. ks. Kamilowi Kowalczykowi.

Nowością podczas IX edycji Dni Muzyki Kościelnej był I Międzyparafialny Przegląd Schól Kościelnych, który odbył się 24 listopada w kościele pw. Najświętszego Serca Pana Jezusa w krakowskich Pychowicach. 
23 listopada w bazylice św. Floriana zabrzmiał koncert pt. Antiqua et nova carmina sacralia. W wykonaniu chóru kameralnego Lege Artis pod dyrekcją Agnieszki Treli-Jochymek zabrzmiały utwory m.in.: Tomasa Luisa da Victorii, Williama Byrda, Antona Brucknera, Mikołaja Gomółki, Pawła Łukaszewskiego.

24 listopada w kościele pw. św. Stanisława BM na Dąbiu odbył się koncert chóralno-organowy w wykonaniu zespołu Art Vocalis. Zabrzmiały kompozycje: Franza Liszta, Jakoba Arcadelta, Henryka Botora, Mikołaja Gomółki, Georga Friedricha Händla. Utwory organowe wykonał i dyrygował Maciej Banek.

Tego samego dnia w kościele pw. Najświętszego Serca Pana Jezusa w Brzeźnicy zorganizowano koncert, podczas którego wystąpili: s. Susi Ferfoglia - organy i Tomasz Ślusarczyk - obój. Zaprezentowano kompozycje Marcela Dupré, Tomasa Albinoniego i Maurice’a Duruflé oraz antyfony gregoriańskie.

W ramach IX Dni Muzyki Kościelnej odbyły się ponadto koncerty organowe w następujących kościołach: bazylika św. Floriana w Krakowie, kościół pw. Narodzenia św. Jana Chrzciciela w Rzeszotarach, kościół pw. Najświętszej Maryi Panny Matki Kościoła w Krakowie, kościół pw. Miłosierdzia Bożego na osiedlu Oficerskim w Krakowie. Wystąpili w nich wykładowcy i studenci Międzyuczelnianego Instytutu Muzyki Kościelnej.

Jak co roku w ramach Dni Muzyki Kościelnej zorganizowano również kolejną edycję Krakowskiego Konkursu Młodych Organistów.

Dni Muzyki Kościelnej w Archidiecezji Krakowskiej wpisały się w kulturalny kalendarz Krakowa. Już od 9 lat w listopadzie kościoły Krakowa i archidiecezji krakowskiej rozbrzmiewają muzyką inspirowaną Słowem i Tajemnicą Przedwiecznego, pochodzącą z nieprzebranego skarbca muzyki kościelnej. Starannie dobrany repertuar zawsze koresponduje z sakralnym charakterem wnętrza, bowiem

kościołów nie można uważać za zwyczajne miejsce „publiczne”, mogące służyć wszelkiego rodzaju zgromadzeniom. Są to miejsca święte, przeznaczone wyłącznie i na stałe, od momentu ich konsekracji lub poświęcenia, do sprawowania kultu Bożego ${ }^{1}$.

Organizowane w ramach Dni Muzyki Kościelnej koncerty pozwalają przybliżyć twórczość wielkich kompozytorów mieszkańcom mniejszych miejscowości w archidiecezji krakowskiej. Warto zauważyć, że są one często jedyną możliwością spotkania wiernych z wysoką kulturą, a przez to znacząco wpływają na kształ-

${ }^{1}$ Instrukcja Kongregacji Kultu Bożego, O koncertach $w$ kościotach, 5. 
towanie ich gustów muzycznych. Z kolei kursy mistrzowskie i inne wydarzenia towarzyszące pozwalają organistom, studentom i wszystkim zainteresowanym na spotkanie z wybitnymi osobowościami artystycznymi i naukowymi z całego świata. Takie spotkania zawsze są niezwykłe, bowiem mobilizują do pracy nad własnym warsztatem muzycznym, pogłębiają wiedzę i poszerzają horyzonty. Dni Muzyki Kościelnej, pozostając w pamięci osób aktywnie w nich uczestniczących, stają się dla wielu inspiracją do dalszych działań. 